Article

\title{
Networked News Participation: Future Pathways
}

\author{
Sue Robinson * and Yidong Wang \\ School of Journalism and Mass Communication, University of Wisconsin-Madison, Madison, WI 53706, USA; \\ E-Mails: robinson4@wisc.edu (S.R.), wang797@wisc.edu (Y.W.) \\ * Corresponding author
}

Submitted: 3 July 2018 | Accepted: 24 August 2018 | Published: 8 November 2018

\begin{abstract}
Civic participation in news production has been a trend under academic scrutiny for at least two decades. The prevalence of digital communication and the dominance of proprietary platforms are two combining forces that disrupt the established journalistic norms. In this article, we investigate news participation and make three grand statements regarding: 1) the holistic definition of participation, 2) the network structure of participation delineating the power dynamics of different media actors, and 3) the transnational context of participation exhibiting the structural constraints within nation-state sovereignty. It is our argument that news participation as a civic act in the digital, globalized age has not fundamentally democratized the information flow as early optimists predicted. Instead, a group of "information elite" have risen to power due to their access to institutional resources, their advantageous positioning in the media ecology, and their entrenchment in the dominant ideology. Participation on proprietary platforms can be easily co-opted to serve the interest of the new information elite.
\end{abstract}

\section{Keywords}

civic participation; news participation; participatory journalism; proprietary platforms; social media

\section{Issue}

This article is part of the issue "News and Participation through and beyond Proprietary Platforms in an Age of Social Media", edited by Oscar Westlund (Oslo Metropolitan University, Norway) and Mats Ekström (University of Gothenburg, Sweden).

(C) 2018 by the authors; licensee Cogitatio (Lisbon, Portugal). This article is licensed under a Creative Commons Attribution 4.0 International License (CC BY).

\section{Introduction}

Participation in "acts of news" (Robinson, 2014) as a discourse on proprietary platforms opens up a civic space for knowledge building-or at least this is the way our actions in digital social places are supposed to feel. But since this space is constrained by the existing hierarchically oriented societal infrastructure, new participatory forces are prone to be appropriated by the social, institutionally entrenched elite to perpetuate such power structures. Civic actors who align with dominant ideologies now show a technological savvy to immerse themselves into the networked media ecology to advantage. Quandt (2018) points out that "dark participation", such as manipulative disinformation and outright trolling, has long been a twin force parallel to the positive side of participation in the cyberspace. In their reflection on the scholarly writings about digital participation, Lewis and Molyneux (2018) question the presumptive conceptualization of civic discourses on social media as positive, representative, and decisive. And yet never before have marginalized voices, social movements, and nonprofits had such access to at-the-ready mass communication outlets; never before have whistleblowers, good Samaritans, and oppressed citizens found audiences to effect change at local and global levels; and never before have we had such networks available to us as individuals to keep up with friends and colleagues, look for jobs, decry our politics, or seek community. Scholarship on "participation" has begun to debunk the hype and nuance participatory practices in consideration of the various contexts within which it is exercised. This work is so important as our lives become more and more entangled with social-media's proprietary platforms over which we 
have very limited control and within which our very souls are laid bare for advertisers, political operatives, and others who may or may not have our best interests at heart.

Our aim in this essay is to make three grand statements about the science and art of participation: the holistic definitions of participation, the network structure of participation, and the transnational context of participation. First, we will articulate what is meant by "participatory". In doing this, we explore the epistemological roots of participation as a civic act, considering the multiple layers of participation as something done both as an individual and also as part of a governing system of knowledge dissemination and control (Carpentier, 2015; Melucci \& Keane, 1989). Second, we offer a typology of participatory roles, drawn from Robinson's research $(2016,2018)$. We complicate those roles by situating them within a structuring system of networked information exchange that is directed by power dynamics. Third, we think transnationally about these roles in the context of proprietary systems of distribution according to government-media relationships (Hallin \& Mancini, 2004). Wide variances exist on the availability of interactive features on news and social sites even within the borders of the same democratic country (Suau \& Masip, 2014). We note too that the very definition of "participation" morphs according to the locality and its political and information infrastructure; each place has its own structuring system with varying formal/informal relationships as well as different restrictions and allowances for participation in mediated spaces.

Our fundamental argument is that network-savvy, prolific members (often representing some segment of the status quo, but not always) are forming a new "information elite" who are reconstituting information flows at all levels of society. As such, this thinking advances Robinson's categorizations of participatory roles; the position of some individuals as being highly networked with access to proprietary platforms determines the amplification of voice. Underlying structures such as legacy media platforms or authoritative institutional sites privilege production circulation for many participants-making them a new kind of elite because of their access to the information stream, especially that which flows among policymakers. For others who are less connected, elite status is more elusive until citizens are able to manipulate the communication networks - and their constraining and enabling forces-in an advantageous manner.

Furthermore, the decline in news outlets locally means that citizens globally are exposed to a proliferation of national news and radio talk shows that tend to be niche oriented-e.g., Fox or MSNBC in the United States-alongside a plethora of content from local activists and politicians, NGOs, and multinational corporations crowding the public deliberative sphere. Holt (2018) captures how some of these actors establish an "anti-system" niche in the information flow and brand themselves as alternative media sources challenging the perceived "established system", whose interest is allegedly represented and reinforced by the mainstream media. Meanwhile, trust in information sources becomes a scarce good as people are now more aware of the agendas promoted by niche news sources. According to the Digital News Report conducted by Reuters Institute (2018), proprietary platforms where those news sources aggregate may risk losing their participatory appeal to more private messaging services because of concerns over misleading information and breach of user privacy.

Thus, this article will interweave the intersecting forces in play around the civic task of news participation with our advanced understandings of digital networks, normative hierarchies governed by dominant ideologies, and new connectivity among global nation-states. Citizens' participation in news production serves a civic function as information is gathered and disseminated to advance certain agendas concerning the daily life of citizens. Conceptually, such participation is a continuation and expansion of Zukin, Keeter, Andolina, Jenkins, and Delli Carpini's (2006) model of civic engagement, which entails purposeful acts of problem solving and community building. The civic nature of news participation gives another layer of relevance to our argument about information elite, whose undue privilege can potentially undermine the health of participatory news networks-with one outcome being the lessening of any civic impact. In the conclusion, we will focus on the future directions for research on news participation, thinking about where we have already been and the trends of polarization and isolationism internationally as well as the complicated job of the participating citizen today.

\section{Participation and Its Structures}

\subsection{Defining Participation}

Vague and fickle, interdisciplinary and multi-dimensional, the concept "participation" eludes a strict consensus of definition (Carpentier, 2015; Fierlbeck, 1998; Jenkins, 2013; Literat, 2016; Pateman, 1970). According to Jenkins (2013, p. 271): "it becomes more and more urgent to develop a more refined vocabulary that allows us to better distinguish between different models of participation and to evaluate where and how power shifts may be taking place". Participation thrives authentically only within a reciprocal relationship between two parties; the more engagement journalists have with citizens, the more community benefits from such participation (Borger, van Hoof, \& Sanders, 2016; Harte, Williams, \& Turner, 2017; Lewis, Holton, \& Coddington, 2014). For example, García de Torres and Hermida's case study (2017) of journalist Andy Carvin depicts a constructive collaboration with public users of social media to report on breaking news. When citizens have capacity to tell their own stories to wide audiences, they "participate" in information flows of communities in ways that increase the feeling of belonging (Costera Meijer, 2013; 
Nip, 2006; Robinson, 2009; Wall, 2017). Anderson and Revers (2018) define the epistemology of news participation as "a form of journalistic knowledge in which professional expertise was modified through public interaction" (p. 26). However, the normative ideal of participatory epistemology has been challenged by the hypercommercialization of audience engagement and the abusive use of participation to promote anti-democratic ideologies (Anderson \& Revers, 2018; Quandt, 2018). Meanwhile, journalism studies scholars have explored how digitized "participatory journalism" undermines the press' authority (Bowman \& Willis, 2003; Robinson, 2011; Singer, 2011; Wall, 2017). Within the journalistic profession, there is confusion and a lack of standard regarding how to moderate participation so that institutionally produced news is not submerged by falsity and incivility (Boberg, Schatto-Eckrodt, Frischlich, \& Quandt, 2018).

Carpentier (2015) in his attempt to untangle the varying meanings of the concept pulls from scholars such as Melucci and Keane in their 1989 declaration that participation "means both taking part, that is, acting so as to promote the interests and the needs of an actor as well as belonging to a system, identifying with the 'general interests' of the community" (p. 174). Ultimately, he lands on a definition that delineates the concept of participation from two others-access and interactivity, though he suggests that these two are dimensions that insert possibilities. Furthermore, Carpentier argues for a comprehensive understanding of any participation as being representative of a more macro struggle for ideological supremacy:

Debates on participation are not mere academic debates but are part of a political-ideological struggle for how our political realities are to be defined and organized. It is also not a mere semantic struggle, but a struggle that is lived and practiced. In other words, our democratic practices are, at least partially, structured and enabled through how we think about participation. The definition of participation allows us to think, to name and to communicate the participatory process....As a consequence, the definition of participation is not merely an outcome of this politicalideological struggle, but an integrated and constitutive part of this struggle. (Carpentier, 2015, p. 18)

This article accepts this holistic articulation of participation as a social construct reflective of and shaped by numerous forces at work. This definition recognizes that many kinds of participation exist with its actants of various intentions and situations. When we explore participation as such, we must reveal the constraints and enabling mechanisms that generate outcomes (whether those outcomes come in terms of democratic experiences, social bonding, political/cultural capital, revenue, or perhaps something more malevolent like wide-spread "fake news" and propaganda). In other words, as we each participate in digital information infrastructures-in the ebb and flow of production and consumption through posting, friending, sharing, linking, pinging and other participatory acts-it matters where we are located (geographically, yes, but also culturally, racially, economically, politically etc.), when, why, and how. Certain "mechanisms" at work might entail national regulations, workplace protocols, or the proprietary-platform structures that impose rules and structures around participating. In addition, the vast underlying networks these proprietary platforms depend upon blend with our offline circles and vice versa-meaning that "participation" often results in unintended connections and associations that we may or may not have wanted.

The structures of participation rely on two major propositions: one, who is producing content and what role are they playing in the overall system of information exchange; and, two, what power dynamics are at work especially in consideration of the distribution infrastructure. We detail both below.

\subsection{Participatory Actors}

Regarding the first structural consideration, much scholarship has documented participants in information exchange. Lewis and Westlund (2015) gave weight to producers but also to the algorithms, cross-media platforms, network properties, and other dimensions that interrelate. Scholars catalogue the nature of digital participation, distinguishing between crowdsourcing, machine work, and more traditional production (EstellésArolas \& González-Ladrón-de-Guevara, 2012, also see García de Torres, Edo Bolós, Jerónimo, Yezers'ka, \& Herrera, 2015; Hedman \& Djerf-Pierre, 2013; Thurman \& Walters, 2013). Indeed, motivations for participations vary widely (Borger et al., 2016; Costera Meijer, 2013; Kormelink \& Meijer, 2017; Wall, 2017). Ahva (2017) studied the "inbetweener" citizens who do not quite reach the level of journalist but still produce. Holton and BelairGagnon (2018) describe the peripheral workers in journalism, including citizen bloggers, programmers and analytical professionals, and rebels and reformers within institutional journalism, as "strangers" to disrupt the established rules of journalism. Ruotsalainen and Villi (2018) notice that a hybrid practice of both journalistic objectivity emphasizing professional fact-gathering and open-ended dialogism featuring audience interaction emerge in the form of "entrepreneur journalism". And Hermida suggests we are heading toward a mass collaboration of citizens participating on a large scale with journalists (2010; Garcia de Torres \& Hermida, 2017). In this new information-based world, journalism authority and industry control diminish, leading to deprofessionalization (Splichal \& Dahlgren, 2016). This section explores what role all of those producing information play in a media ecology.

Primarily, this article highlights a typology (see Table 1) Robinson (2016) did in collaboration with Kettering Foundation and that later served as the foundation for 
her book titled Networked News, Racial Divides: How Power \& Privilege Shape Public Discourse in Progressive Communities (2018). She broke the varying levels of participants down according to networked properties or information-exchange roles comprising digitized media ecologies today. The typology includes:

- "Institutional Producers": Those entities considered to be information royalty who have been around a long time and have the capability to allow or prohibit participation because they own their own platforms and have dominion over mass spaces that tend to be well known as "brands" among constituents. These are news organizations, government programs, churches, etc. who can bypass media to host their own information exchange and operate at the macro, institutional (or even, systems) level of information production.

- Situated inside these realms are many individuals ("Individual Institutional Producers") who carry the brand torch via their own participatory platforms such as their blogs, Twitter, or Facebook. Their highly networked scaffolding combined with their nimble relationship-building capacity as individual personalities makes this role in the emergent media ecology particularly powerful.

- "Alternative Sites" refer to media organizations like ethnic publications that establish outlets to challenge the status quo. Digital technologies have meant huge audience growth for these sites, which take advantage of participatory nature of interactivity. These entities are not quite institutional and established, but instead exist at the meso level of the information society.

- "Network Facilitators" maintain the network through aggregation and algorithms, tend to be automated, and operate at the meso level of society because they make visible what is happening on the individual level with what is being produced at the macro level. Google, Facebook, Twitter and other distribution platforms that are commercially owned and for-profit play key roles as essential network facilitators in information exchange.

- "Community Bridges" are those individuals or entities who circulate in multiple groups within the overall information network and who have the capacity to broker relationships. In this work, "Community Bridges" can prevent a situation where silos of conversation dominate by forging connections where there were none-at least in theory.

- "Niche Networkers" are those key influencers around specific topics or special interests whose participation in information production populates the discussion. Sometimes these can be "Community Bridges" as well, but more and more often, they are not. Robinson's research (2018) demonstrates that these individuals, operating at the micro level, make use of all the digital platforms available and tend to be prolific across the informationexchange platforms around a particular issue.

- "Issue Amplifiers" are those engaged citizens who might link or share public-affairs data on their Face-

Table 1. Participatory roles in an emergent ecology in local community.

\begin{tabular}{|c|c|c|c|c|}
\hline Roles & Function & System Level & Actors & Platforms \\
\hline $\begin{array}{l}\text { Institutional } \\
\text { Producers }\end{array}$ & $\begin{array}{l}\text { Set hierarchy for information } \\
\text { flow }\end{array}$ & Macro & $\begin{array}{l}\text { Institutions such as the press } \\
\text { or school district (as entities) }\end{array}$ & $\begin{array}{l}\text { Newspapers, radio, } \\
\text { television, website, } \\
\text { social media accounts }\end{array}$ \\
\hline $\begin{array}{l}\text { Individual } \\
\text { Institutional } \\
\text { Producers }\end{array}$ & $\begin{array}{l}\text { Perpetuate hierarchy } \\
\text { of flow }\end{array}$ & $\begin{array}{l}\text { Macro- } \\
\text { Meso- } \\
\text { Micro }\end{array}$ & $\begin{array}{l}\text { Individual reporters, politicians } \\
\text { or others associated with } \\
\text { institutions, offshoot websites }\end{array}$ & $\begin{array}{l}\text { Reporter blogs, social } \\
\text { media accounts } \\
\text { of employees }\end{array}$ \\
\hline $\begin{array}{l}\text { Alternative } \\
\text { Sites }\end{array}$ & $\begin{array}{l}\text { Groups or established } \\
\text { entities challenge } \\
\text { status quo }\end{array}$ & Meso & $\begin{array}{l}\text { Nonprofessional journalism } \\
\text { entities with general-interest } \\
\text { content }\end{array}$ & $\begin{array}{l}\text { Newspapers, radio, } \\
\text { websites, blogs, forums, } \\
\text { Facebook Group Pages }\end{array}$ \\
\hline $\begin{array}{l}\text { Network } \\
\text { Facilitators }\end{array}$ & $\begin{array}{l}\text { Maintain the network, } \\
\text { aggregate content }\end{array}$ & Meso & Automated program & $\begin{array}{l}\text { Website, blogs, Google, } \\
\text { Facebook, Twitter }\end{array}$ \\
\hline $\begin{array}{l}\text { Community } \\
\text { Bridges }\end{array}$ & $\begin{array}{l}\text { Individuals or sites } \\
\text { that connect otherwise } \\
\text { disparate communities }\end{array}$ & $\begin{array}{l}\text { Meso- } \\
\text { Micro }\end{array}$ & $\begin{array}{l}\text { Community leaders (could be } \\
\text { reporters, activists, bloggers) }\end{array}$ & $\begin{array}{l}\text { Blogs, Facebook, } \\
\text { Twitter, social media }\end{array}$ \\
\hline $\begin{array}{l}\text { Niche } \\
\text { Networkers }\end{array}$ & $\begin{array}{l}\text { Individuals not associated } \\
\text { with institutions who } \\
\text { produce copious content } \\
\text { on an issue }\end{array}$ & Micro & $\begin{array}{l}\text { Special-interest bloggers, } \\
\text { activists, citizen } \\
\text { journalists }\end{array}$ & $\begin{array}{l}\text { Blogs, Facebook pages, } \\
\text { websites, social media }\end{array}$ \\
\hline $\begin{array}{l}\text { Issue } \\
\text { Amplifiers }\end{array}$ & Share, discuss & Micro & Engaged citizens & $\begin{array}{l}\text { Facebook, Twitter, } \\
\text { email }\end{array}$ \\
\hline
\end{tabular}


book pages and Twitter feeds, or other social media but who are not regularly producing content around a specific topic like "Niche Networkers". In a world where 1.37 billion active daily users globally are on Facebook alone (and some 330 million on Twitter), many many individuals might consider themselves to be participating in some kind of micro-level issue amplification.

These roles of production work in concert with participatory actions that make up the information flow in local communities as well as national media systems. From the micro-level individual poster on Facebook or Weibo to the mega-systemic, macro-level distributive platforms that operate as "network facilitators", each role contributes, influences, undermines, transforms, enhances, and perpetuates the social, political, economic forces in the civic society of every country around the globe. It is how people and entities are networked that determines the direction and volume of information. Those networks result from both intentional actions as well as latent effects, draw from both offline and online relationships, and reflect the circumstances at work in the overall media ecology at micro, meso, and macro levels. It should also be noted that these roles are not discrete categories.

\subsection{Power Hierarchies in Proprietary Distribution Systems}

Second to consider is the success of those information interactions as determined not only by the networked amplifications-and these would include the algorithmic properties of platforms - but also by the dominant ideology and power dynamics of a particular sphere. Participation depends not only on platform access and availability, and not only on networked connections and amplification (Usher, 2017), but also on the internal and external forces at work before that person presses the submit button. Some scholarship has posited that to "participate" is to engage in a duality-on the one hand, it means to act as an individual with intention for some expected benefit, and on the other, it also suggests to become a "part" of something bigger than the individual, to participate in something like a community or system (Carpentier, 2015; Melucci \& Keane, 1989). This duality means that those studying participation as a phenomenon must appreciate not only the individual participators-their motivations, influences, impacts, challenges and strategies-but also the structural conditions surrounding that participation. This latter means consideration of the power dynamics at work, the specific networked infrastructure supporting (or inhibiting) participation, and the influencing actions of others in that realm. A dominant ideology that governs the information-exchange patterns can help determine the success of any participation. Every participant plays a role within that system, whether they mean to or not.
Every act of participation creates a ripple or a splash in a massive stream of information.

Thus, participation comes with caveats. Off of Carpentier (2009, 2015), Pateman (1970), and Arnstein (1969), Literat (2016) lays out "degrees of participation" where both the actions and its outcomes exist along a continuum axis that depend on a huge host of factors. Someone merely posting as an "Issue Amplifier" on their own have little influence in the network without some kind of facilitator or key connection that can send that content over a bridge into other places (Usher, 2017). Citizens on their own must generate and take advantage of highly networked connections if they want their content to make an impact. Without that connection, these producers are merely practicing "citizen participation" as opposed to "civic participation". One role news organizations perpetuate is a constant repairing of authoritative fissure through very intentional repressing of "non-professional" content produced by "amateurs". Analyzing Australian journalists' adoption of Twitter as a news dissemination platform, Bruns (2012) revealed that the tension erupted when news organizations migrated to the social media sphere and cohabited and competed with "amateur" news producers actively attacked their institutional authority. This policing of journalistic authority is an important point to remember because so much scholarship has heralded the opportunities of the Internet to diffuse power hierarchies (e.g., Castells, 2013), but institutions remain entrenched as controllers of information. Carpentier (2009, p. 408) calls the utopian outlook on digital possibilities a "reductionist discourse of novelty". Hindman (2008), Robinson (2018), and many others have shown how offline echelons temper such rapture.

The word "participatory" evokes a utopian democratic agency, yet digital production manifests something more nefarious, or at the very least, often represents a co-opting of that agency. Way back in 2002, Andrejevic warned of the "exploitation of self-disclosure" in interactive media production, which transforms any act of participation on the part of citizens into free labor for commercial institutions and subjects private information to state and corporate surveillance. More than a decade later, Silverman (2015) suggested we have entered a "surveillance state" that amounts to "spying" on the part of social media platforms like Facebook and Twitter. Mass-scale surveillance enabled by "digital footprints" has become an integral part of the capitalist state machine that rationalizes domination through optimizing economic productivity and regulating the technocultural discourses circulating in the media (Bolin \& Jerslev, 2018; Fuchs, 2015). In this accounting, "participation" within proprietary entities fails as an act of individualism but rather represents acts of subjugation by the owners of proprietary platforms. In any such model, only a partial participation is present (Pateman, 1970). Arnstein (1969) points out that when participation occurs without the power to effect change, frus- 
tration reigns as only one party sees benefits. For "full" (Pateman, 1970) or "maximalist" participation to be achieved, power between the participatory parties must be shared equally across the continuum of production to consumption (Carpentier, 2015; Servaes, 1999; White, Nair, \& Ascroft, 1994). "Participation", then, goes somewhat beyond mere "access" or even "interactivity", suggested Carpentier (2015).

\section{The Transnational Context}

In addition to these more internally determined structures of participation, we must also understand external contexts, specifically through a transnational lens. In their model of comparative media systems, Hallin and Mancini (2004) put forward a set of parameters, including news market, political parallelism, journalistic professionalization, and state intervention, to measure how media operate in a given locality. This comparative framework suggests that the shape of media landscape is tied to specific nation-state contexts.

A felicitous case to demonstrate this complexity of civic participation in news production is China. Historically, the state has been playing a central role in media production since the Communist rule was established in 1949 (Zhao, 2011). It is too simplistic to conceptualize state intervention just as political censorship and suppression of civic participation. According to Zhao, the influence of the Chinese state also penetrates into the "democratic" dimension of media praxis, such as marketoriented commercialization, journalistic professionalization, and even the public's expectation of the "Fourth Estate". Through analyzing Chinese journalists' attitude toward user-generated content, Tong (2015) found that Chinese journalists (as "individual institutional producers") associated their professional identity closely with their affiliation to media organizations and deemed participatory journalism an outsider practice. In the Chinese context, such organizational affiliation, or danwei, entails both an employment relationship and a consent from the state. When performing the "watchdog" duty to monitor state power, Chinese journalists often need to step outside the institutional structure of danwei and switch their identity to "citizen journalists" (Xu, 2015; $\mathrm{Yu}, 2011)$. In the Chinese case, the ecological position of "individual institutional producers" is more a disjuncture rather than an extension of the institutional media agenda. It is difficult for professional journalists to bridge communities, facilitate networks, or cultivate niches despite their network position. Participatory news production is not only a challenge to journalistic authority, but also a challenge to state authority over journalism.

Social media constitute a crucial site for civic participation in China, both for journalists and for citizens (Liu, 2017). But user activities on social media are under comprehensive government surveillance as well. A group of opinion leaders emerged on Chinese social media, especially Weibo, around 2010. This group of social media opinion leaders, nicknamed "big V" after their verified VIP account and comprising professionals, pundits, and celebrities in the entertainment industry, served as the collective voice of grassroots netizens and gained significant power to guide public attention to various social affairs (Schneider, 2017; Svensson, 2014). In 2013, the government crashed down many "big V" accounts, accusing them of circulating untruthful claims and disturbing social order. This meso-level entry in the participation network was eliminated. Meanwhile, the Chinese government employed "counter-networking" agents who created more than $\mathbf{4 0 0}$ million bot messages yearly to override participatory voices on social media (King, Pan, \& Roberts, 2017). Even the digital infrastructure of civic participation is infused with state power. Major technology companies in China rely heavily on the government for favorable policies. In exchange, domestic service providers enforced vigorous self-censorship, mandated identity verification, and made user data fully available to the government.

As demonstrated in the Chinese case, understanding participation through a transnational lens rejects a mechanical application of Robinson's $(2016,2018)$ typology of ecological roles. The interaction between "institutional producers" and other more amateur actors in the ecology (such as "niche networkers" or "issue amplifiers") affects a media ecology through the broader social structure of the given locality. Proprietary platforms can facilitate civic participation, but they are essentially private companies feeding on commercial success. Despite operating multinational businesses, platform companies like Google and Facebook-or "network facilitators" - do not have the means or the incentive to challenge local power arrangements that privilege certain social groups while oppressing others. Therefore, participatory media production should not be branded with either a teleological transcendence promising an ultimately civic paradise or a technological determinism glorifying the media platforms. Participation itself is a site of power struggle.

\section{Participation and the New Information Elite}

When we talk of "participation" in the digital age and understand that power must be a part of those discussions, we are speaking of the impetus for the formation of an "information elite", who understand how best to manipulate content, digitally, and then to distribute it within a highly networked mediated infrastructure. Any production by savvy actors or machine agents occurring on densely connected networks will result in a more superior impact. But we also know from viral videos, for example, that even smaller ecological players such as "niche networkers" or even "issue amplifiers" can "work" their networks to achieve greater participatory success. In effect, these non-institutional citizens-though connected in other ways as activists, community leaders, engaged experts, etc. - achieve status as a new information elite. We can see this participatory success playing out 
at macro, meso, and micro levels with information elite infiltrating all the typological information-exchange, ecological roles of Robinson (2016, 2018).

At the macro or systems level, state power dynamics, commercial conglomerates, and "institutional producers" regulate proprietary platforms that commodify user-generated content, gain profits from online traffic, and set the rules for participation. Companies that operate at the macro-level such as Alphabet, Facebook, and Amazon ("network facilitators") join with other infrastructural and distribution platforms like AT\&T and media empires like News Corp to form a new elite business club, which has significant control over people's daily communication and backs up a digital elitism in the name of participation. This prioritization of corporate interests is regulated by national policies and interests in exchange for administrative advantages. In this macro functionality, participation feeds these power structures.

These conglomerates nurture the networks at the meso-level via algorithms and aggregation and connect macro and micro levels of information participation. Anderson (2011) noted that we are moving toward "algorithmically oriented production" processes (p. 540) where machines themselves are "participating" by producing content (Dörr, 2016). The prevalence of computational tools in news production and circulation brings about new ethical and analytical questions regarding labor relations, data collection, and algorithmic transparency (Diakopoulos \& Koliska, 2017; Lewis, 2015). Through their meso-level algorithmic strategies, platform companies co-opt micro-level citizen "participation" under the guise of civic acts. When we theorize about participation, we need to remember that algorithms are privately programmed, as Neff (2018) and others are researching; participants can employ "search engine optimization" (SEO) strategies, but in the end if their content properties are not picked up by the algorithms for distribution of Facebook, Google and other monolithic technology companies, the material goes nowhere (Nguyen, Kelleher, \& Kelleher, 2015; Wang, 2015).

At the micro-individual level, most grassroots participators such as "issue amplifiers" or even would-be "community bridges" are constrained by these meso and macro functionalities. In the case of thousands of social media "celebrities," they form the silent pedestal of the economy of digital participation rather than democratize channels to set social agendas. Participatory platforms facilitate the mobilization and self-organization of alternative voices in their bid for challenging existing hierarchies. But these platforms, or rather their owner companies, rarely protect alternative voices from suppression by institutional or state powers. Finally, people who are better-off socially gain more from digital participation, while marginalized communities face more challenges in directing participation to their causes (e.g., Wang, 2018). That is, the class "information elite" is not solely about being active in the information flow and voicing opinions on digital proprietary platforms. They are the ones whose voices are really heard and amplified by the participation network because of their entrenchment into the macro-level structures.

Our major argument here is one that advances and nuances Robinson's 2018 typology of roles. Robinson delineated the different kinds of actors at work in the information flows of local community media ecology and then theorized how power dynamics influenced those actors' effectiveness. We are going one step further, noting that the literature points to a growing "information elite" that bubble up from that typology. The online and offline activity of these producers combine with an astute manipulating of their network position, the algorithms of the platforms and distribution systems, and their country's superstructure and regulations to create new groupings of successful participation. The members of these participatory groups hail from throughout Robinson's categorization of roles-not only institutional producers but also niche networkers and issue amplifiers. However, not all producers in these categories reach an elite status-defined as the point at which produced content or other kinds of participation in information exchanges are widely shared and discussed publicly. Whether they do or not depends upon the structures behind the participation. Although Robinson and Carpentier both write at length about actors and their power dynamics, neither aggregate the specific forces that include institutional commodification of participation, distribution systems' varying constraints and enablings, or transnational contexts or articulate the result in the same way as this concluding essay for this thematic issue.

\section{Conclusion}

The common narrative that identifies civic participation as a driving force for democracy presumes a certain normative ideal, which entails mobilizable publics and adaptable institutions (Jasanoff, 2011). Participation is considered civic and constructive when it empowers individual citizens to pressure institutional producers toward internal change. Carpentier (2015) pointed out how any effects of participation in one field may be felt in other arenas of that person's life. Playing this out, we imagine a non-networked person, perhaps an "issue amplifier" who posts often on the topic of social justice and in the course of that participation, she is motivated to participate offline as well. An updated version of this empowerment narrative connects civic participation with self-actualization and struggles in private lives (Bennett, 2008; Kim, 2012), highlights the ability of institutions to incorporate civic participation in political mobilization (Karpf, 2012; Kreiss, 2012), and centers digital media as the facilitator for both trends (Bennett \& Segerberg, 2013; Castells, 2012). This narrative is reflected in theorization of participatory journalism, with citizen content producers as the grassroots, the established news organizations as the institution, and digital media as the bridge between the two. 
However, the democratic promise of civic participation is not a fixed premise; it is constituted with cultural identities, ideological predispositions, social hierarchy, and professional journalistic praxis (Dahlgren, 2012). Furthermore, the transnational context of participation complicates the structural constraints within nation-state sovereignty, among other factors. The triangular relationship between individuals, their institutions and the digital-media connectors varies according to how democracy is organized in a particular society. As we have argued in this essay, "participation" is not merely the action that follows interactivity allowed by the Internet but reflects systems at work. This new elite class of participants are highly networked individuals who operate within structures and infrastructures that help amplify their information production according to already established sets of rules and regulations. Because of this amplification, the elite groups can contribute to the discursive isolation of more marginalized citizens and countries, just as easily as they can raise voices. Future research might go deeper into this question of the nation-state influence on individual participation, especially in an age of globalization when time and space are perverted and multiple countries are involved with a single post or tweet. How do the geographic, cultural, economic, or political backgrounds of a participant affect what is produced, why it is produced, and where it travels?

This situation is exacerbated by global trends of intentional division and authoritarianism combined with an aggressive animus toward formal channels of participation such as the vitriol against professional journalists coming from leaders like President Donald Trump in the United States. Increasing polarization and isolation will continue despite the increasing capacity for the amplification of ideas and the nurturing of deliberation. If all participants in the new attention economy share content that is polemic and quarrelsome without being dialogic or deliberative, can we still consider such actions to be civically oriented? Here we see the potential for new lines of research investigating what Quandt (2018) in this thematic issue called "dark participation," which is the "evil flip side of citizen engagement" (p. 37). Dark participation, according to Quandt, would entail activities such as trolling, cyberbullying, or the more nefarious and explicitly produced "fake news" created by Russian operatives to undermine U.S. democracy, for example. In this essay he begins a typology of these "dark" participants, but as this is a huge and emergent realm of participation, much more theorizing needs to happen. How do these citizens with such malevolent intention work? How do their countries of origin and their countries of attack differ in their informational infrastructure? What makes them effective as powerful, networked actors with real influence on information flows-and ultimately on political events such as the 2016 U.S. presidential election? What are the structuring conditions that lead to success or failure of "dark participation"? These particular dark actors would constitute a new role in Robinson's categorization certainly, but the parameters of that role are still emerging and evolving.

Our argument about information elites in networked news participation can help to give some directions for answering these questions. In the context of the United States, a group of alt-right "participants" rose to prominence with their savvy use of digital media platforms like Reddit and 4chan. Marwick and Lewis (2017) pointed out that although the xenophobic, racist, and sexist ideologies the alt-right groups promoted might not represent the mainstream opinion climate, their messages got picked up by right-wing politicians and then the mainstream media. The alt-right groups' successful entry into the information flow, which perpetuates the social hierarchy disproportionately benefiting a few, reveals the interaction between effective use of network and entrenchment in the macro structure.

At the same time, interactivity has opened new pathways for information exchange, and burgeoning lines of scholarship must situate that fresh new power as well, along with the subversion and even revolution. Even the new "information elite" emerging within these socialmedia-enhanced networks must constantly grapple with the explosion of what Castells (2013) called "mass selfcommunicators" who are working side-by-side (sometimes in opposition to and sometimes in collaboration with) more professional communicators hailing from established institutions and organizations. Consider for example the global \#MeToo social-media movement in which hundreds of thousands of women shared stories of sexual harassment; as accusations could be verified, companies took action, firing high-profile men, and committees and fund-raising entities were formed (as in the Hollywood Time's Up legal defense fund for sexual harassment victims), changing professional life in these places. However, such a grassroots movement also embodies contestation among structural powers. Transnationally, information elites were instrumental in making this movement go viral in Western democratic countries. In just a few weeks in the fall of 2017, the hashtag \#MeToo found its way to 85 countries (Collins, 2018). These women ran the gamut in terms of fulfilling different and complementary roles in global media ecologies, with many serving as "community bridges" that spanned continents. But the movement was confronted with state intervention in many informationally repressed countries. In China, the hashtag \#MeToo (both in English and in Chinese) was banned on social media, although the state did not actively suppress the revelation of sex offenders. Under such scenario, movement participants needed to navigate institutional conduits like state media and official reporting systems in addition to "mass selfcommunication" on social media. The power dynamic of the \#MeToo movement also manifested cross-racially. Black activists' earlier promotion of the movement was largely neglected until White celebrities chimed in. The experience of women of color were again marginalized 
after the movement gained international attention. Despite the interactivity of networked participation, the ability to become an information elite is often conditioned by race, gender, sexuality, and socioeconomic status. Therefore, grassroots movements with their birth on social platforms offer much fodder for scholars of participation seeking to understand the characteristics of successful production and sharing in terms of civic work. What are the forces at work when online participation becomes offline change? What are the downfalls when people participate at such breakneck speeds? How do people move between roles in the media ecology, with what motivations and intentions and influences?

This article has explored the multifarious dynamics of acts of participation in a digital, socially networked, globally interconnected world. Recent research has gained a better understanding of how participatory impulses of engaged citizens affect the production of news as a form of knowledge. This concluding piece is part of a thematic issue full of articles that investigate participation. In the introductory piece, Lewis and Molyneux (2018) suggest social media are ephemeral, uncertain things that demand highly contextualized research. Other articles in this thematic issue put forth new theories around the anti-system nature of alternative media regardless of their political stances (Holt, 2018), brief case studies to recount the historical trajectory of an evolving "participatory epistemology" as a new form of journalistic knowledge (Anderson \& Revers, 2018), a hybrid model of audience engagement adopted by entrepreneur journalism (Ruotsalainen \& Villi, 2018), a typology of "peripheral workers" who innovate or disrupt traditional news production inside and outside of the newsroom (Holton \& Belair-Gagnon, 2018), and a deep dive into the German Spiegel Online to understand how comment moderation decisions are made (Boberg et al., 2018). In aggregate they provide both a taking stock of participation research to date in journalism studies as well as an interrogation of participation's status in the field as a construct and phenomenon.

The thematic issue in Media and Communication overall points to a way forward for participation as it continues to evolve for new information roles, changing demographics and power structures, and enduring institutions and nation-state infrastructures. Particularly, these articles question the simplistic understanding of news participation as unconditionally civic and problematize the role of proprietary platforms in the media environment. Established news organizations have long been holding a strong animosity toward digital news aggregators, which are accused of appropriating the content without sending enough advertising revenue back (Chyi, Lewis, \& Zheng, 2016). Nielsen and Ganter (2018) found that the tension between news organizations and proprietary platforms often revolved around the control over communication channels. Although platforms can potentially generate a high volume of traffic, over-dependence to social media monopolies like Facebook renders news producers, including citizen participants, vulnerable to unpredictable changes in technical specifications and marketing strategies that are only accountable to shareholders of platform companies. As a result, the weakened accountability among content, participants, and platforms undermines the capacity of the media system to internally mitigate what Quant (2018) identifies as "dark participation".

\section{Acknowledgments}

The authors thank Kettering Foundation for allowing the reprint of the table from the report: Robinson, S. (2016). Deliberation in networked media ecologies. Dayton, $\mathrm{OH}$ : Kettering Foundation.

\section{Conflict of Interests}

The authors declare no conflict of interests.

\section{References}

Ahva, L. (2017). How is participation practiced by "in-betweeners" of journalism? Journalism, 11(2/3), 142-159.

Anderson, C. W. (2011). Deliberative, agonistic, and algorithmic audiences: Journalism's vision of its public in an age of audience transparency. International Journal of Communication, 5(2011), 529-547.

Anderson, C. W., \& Revers, M. (2018). From counterpower to counter-Pepe: The vagaries of participatory epistemology in a digital age. Media and Communication, 6(4), 24-35.

Andrejevic, M. (2002). The work of being watched: Interactive media and the exploitation of self-disclosure. Critical Studies in Media Communication, 19(2), 230-248.

Arnstein, S. R. (1969). A ladder of citizen participation. Journal of the American Institution of Planners, 35(4), 216-224.

Bennett, L. (2008). Changing citizenship in the digital age. In L. Bennett (Ed.), Civic life online: Learning how digital media can engage youth (pp. 1-24). Cambridge, MA: MIT Press.

Bennett, W. L., \& Segerberg, A. (2013). The logic of connective action: Digital media and the personalization of contentious politics. Cambridge: Cambridge University Press.

Boberg, S., Schatto-Eckrodt ,T., Frischlich, L., \& Quandt, T. (2018). The moral gatekeeper? Moderation and deletion of user-generated content in a leading news forum. Media and Communication, 6(4), 58-69.

Bolin, G., \& Jerslev, A. (2018). Surveillance through media, by media, in media. Northern Lights, 16(1), 3-21.

Borger, M., van Hoof, A., \& Sanders, J. (2016). Expecting reciprocity: Towards a model of the participants' perspective on participatory journalism. New Media \& Society, 18(5), 708-725. doi:10.1177/ 


\section{2}

Bowman, S., \& Willis, C. (2003). We media: How audience are shaping the future of news and information. Reston, VA: The Media Center at the American Press Institute. Retrieved from http://www.hypergene. net/wemedia/weblog.php

Bruns, A. (2012). Journalists and Twitter: How Australian news organisations adapt to a new medium. Media International Australia, 144, 97-107.

Carpentier, N. (2009). Participation is not enough: The conditions of possibility of mediated participatory practices. European Journal of Communication, 24(4), 407-420. doi:10.1177/0267323109345682

Carpentier, N. (2015). Differentiating between access, interaction and participation. Conjunctions, 2(2). doi:10.7146/tjcp.v2i2.22915

Castells, M. (2012). Networks of outrage and hope: Social movements in the Internet Age. Cambridge and Malden: Polity Press.

Castells, M. (2013). Communication power (2nd ed.). New York, NY: Oxford University Press.

Collins, E. (2018, July 10). The global impact of the \#MeToo movement (part I). New York Law Journal. Retrieved from https://www.law.com/newyork lawjournal

Costera Meijer, I. (2013). When news hurts: The promise of participatory storytelling for urban problem neighbourhoods. Journalism Studies, 14(1), 13-28. doi:10.1080/1461670X.2012.662398

Chyi, H. I., Lewis, S. C., \& Zheng, N. (2016). Parasite or partner? Coverage of Google News in an era of news aggregation. Journalism \& Mass Communication Quarterly, 93(4), 789-851. doi:10.1177/ 1461444817701318

Dahlgren, P. (2012). Reinventing participation: Civic agency and web environment. Geopolitics, History, and International Relations, 4(2), 27-45.

Diakopoulos, N., \& Koliska, M. (2017). Algorithmic transparency in the news media. Digital Journalism, 5(7), 809-828. doi:10.1080/21670811.2016.1208053

Dörr, K. N. (2016). Mapping the field of algorithmic journalism. Digital Journalism, 4(6), 700-722. doi:10.1080/21670811.2015.1096748

Estellés-Arolas, E., \& González-Ladrón-de-Guevara, F. (2012). Towards an integrated crowdsourcing definition. Journal of Information Science, 38(2), 189-200. doi:10.1177/0165551512437638

Facebook. (2018). Stats. Facebook Newsroom. Retrieved from https://newsroom.fb.com/company-info

Fierlbeck, K. (1998). Globalizing democracy: Power, legitimacy and the interpretation of democratic ideas. Manchester: Manchester University Press.

Fuchs, C. (2015). Surveillance and critical theory. Media and Communication, 3(2), 6-9. doi:10.17645/ mac.v3i2.207

García de Torres, E., Edo Bolós, C., Jerónimo, P., Yezers'ka, L., \& Herrera, C. (2015). The opportunities, risks, techniques and language of crowdsourcing journalism.
Paper presented at The Future of Journalism: Risks, Threats and Opportunities, Cardiff University, Cardiff, UK.

García de Torres, E., \& Hermida, A. (2017). The social reporter in action: An analysis of the practice and discourse of Andy Carvin. Journalism Practice, 11(2/3), 177-194. doi:10.1080/17512786.2016.1245110

Hallin, D. C., \& Mancini, P. (2004). Comparing media systems: Three models of media and politics. Cambridge and New York: Cambridge University Press.

Harte, D., Williams, A., \& Turner, J. (2017). Reciprocity and the hyperlocal journalist. Journalism Practice, 11(2/3), 160-176. doi:10.1080/17512786. 2016.1219963

Hedman, U., \& Djerf-Pierre, M. (2013). The social journalist: Embracing the social media life or creating a new digital divide? Digital Journalism, 1(3), 368-385. doi:10.1080/21670811.2013.776804

Hermida, A. (2010). Twittering the news: The emergence of ambient journalism. Journalism Practice, 4(3), 297-308.

Hindman, M. S. (2008). The myth of digital democracy. Princeton, NJ: Princeton University Press.

Holt, K. (2018). Alternative media and the notion of antisystemness: Towards an analytical framework. Media and Communication, 6(4), 49-57.

Holton, A., \& Belair-Gagnon, V. (2018). Strangers to the game? Interlopers, intralopers, and shifting news production. Media and Communication, 6(4), 70-78.

Jasanoff, S. (2011). Designs on nature: Science and democracy in Europe and the United States. Princeton, NJ: Princeton University Press.

Jenkins, H. (2013). Rethinking 'rethinking convergence/culture'. Cultural Studies, 28(2), 267-297.

Karpf, D. (2012). The MoveOn effect: The unexpected transformation of American political advocacy. New York, NY: Oxford University Press.

Kim, Y. M. (2012). The shifting sands of citizenship: Toward a model of the citizenry in life politics. The ANNALS of the American Academy of Political and Social Science, 644(1), 147-158. doi:10.1177/ 0002716212456008

King, G., Pan, J., \& Roberts, M. E. (2017). How the Chinese government fabricates social media posts for strategic distraction, not engaged argument. American Political Science Review, 111(3), 484-501. doi:10.1017/S0003055417000144.

Kormelink, T. G., \& Meijer, I. C. (2017). What clicks actually mean: Exploring digital news user practices. Journalism. doi:10.1177/1464884916688290

Kreiss, D. (2012). Taking our country back: The crafting of networked politics from Howard Dean to Barack Obama. New York, NY: Oxford University Press.

Lewis, S. C. (2015). Journalism in an era of big data: Cases, concepts, and critiques. Digital Journalism, 3(3), 321-330. doi:10.1080/21670811.2014.976399

Lewis, S. C., Holton, A. E., \& Coddington, M. (2014). Reciprocal journalism: A concept of mutual exchange be- 
tween journalists and audiences. Journalism Practice, 8(2), 229-241. doi:10.1080/17512786.2013.859840

Lewis, S. C., \& Molyneux, L. (2018). A decade of research on social media and journalism: Assumptions, blind spots, and a way forward. Media and Communication, 6(4), 11-23.

Lewis, S. C., \& Westlund, O. (2015). Actors, actants, audiences, and activities in cross-media news work: A matrix and a research agenda. Digital Journalism, 3(1), 19-37. doi:10.1080/21670811.2014.927986

Literat, I. (2016). Interrogating participation across disciplinary boundaries: Lessons from political philosophy, cultural studies, art, and education. New Media \& Society, 18(8) 1787-1803. doi:10.1177/ 1461444816639036

Liu, Z. (2017). Metro newspaper journalists in China: The aspiration-frustration-reconciliation framework. New York, NY: Routledge.

Marwick, A., \& Lewis, R. (2017). Media manipulation and disinformation online. New York, NY: Data \& Society Institute.

Melucci, A., \& Keane, J. (1989). Nomads of the present: Social movements and individual needs in contemporary society. Philadelphia, PA: Temple University Press.

Neff, G. (2018). Does Al have Gender? Oxford Internet Institute. Retrieved from https://www.oii.ox.ac. uk/events/oii-neff-lecture

Nguyen, D., Kelleher, A., \& Kelleher, A. (2015, April 27). Introducing pound: Process for optimizing and understanding network diffusion. Buzzfeed. Retrieved from http://www. buzzfeed.com

Nielsen, R. K., \& Ganter, S. A. (2018). Dealing with digital intermediaries: A case study of the relations between publishers and platforms. New Media \& Society, 20(4), 1600-1617. doi:10.1177/1461444817701318

Nip, J. Y. M. (2006). Exploring the second phase of public journalism. Journalism Studies, 7(2), 212-236. doi:10.1080/14616700500533528

Pateman, C. (1970). Participation and democratic theory. Cambridge: Cambridge University Press.

Quandt, T. (2018). Dark participation. Media and Communication, 6(4), 36-48.

Reuters Institute. (2018). Digital news report. Reuters Institute. Retrieved from http://www.digitalnews report.org

Robinson, S. (2009). "If you had been with us": Mainstream press and citizen journalists jockey for authority over the collective memory of Hurricane Katrina. New Media \& Society, 11(5), 795-814. doi:10.1177/ 1461444809105353

Robinson, S. (2011). "Journalism as process": The organizational implications of participatory online news. Journalism and Communication Monographs, 13(3), 137-210.

Robinson, S. (2014). The active citizen's information media repertoire: An exploration of community news habits during the digital age. Mass Commu- nication and Society, 17(4), 509-530. doi:10.1080/ 15205436.2013.816745

Robinson, S. (2016). Deliberation in networked media ecologies. Dayton, $\mathrm{OH}$ : Kettering Foundation.

Robinson, S. (2018). Networked news, racial divides: How power and privilege shape public discourse in progressive communities. Cambridge: Cambridge University Press.

Ruotsalainen J., \& Villi, M. (2018). Hybrid engagement: Discourses and scenarios of entrepreneurial journalism. Media and Communication, 6(4), 79-90.

Schneider, F. (2017). China's 'Big V' bloggers: How celebrities intervene in digital Sino-Japanese relations. Celebrity Studies, 8(2), 331-336. doi:10.1080/ 19392397.2017.1311616

Servaes, J. (1999). Communication for development: One world, multiple cultures. Cresskill, NJ: Hampton Press.

Silverman, J. (2015). Terms of service: Social media and the price of constant connection (1st ed.). New York, NY: Harper Collins.

Singer, J. B. (Ed.). (2011). Participatory journalism: Guarding open gates at online newspapers. Chichester and Malden: Wiley-Blackwell.

Splichal, S., \& Dahlgren, P. (2016). Journalism between de-professionalisation and democratisation. European Journal of Communication, 31(1), 5-18. doi:10.1177/0267323115614196

Statista. (2018). Number of monthly active Twitter users worldwide from 1st quarter 2010 to 1st quarter 2018 (in millions). Statista. Retrieved from https://www. statista.com/statistics/282087/number-of-monthlyactive-twitter-users

Suau, J., \& Masip, P. (2014). Exploring participatory journalism in Mediterranean countries: Political systems and national differences. Journalism Practice, 8(6), 670-687. doi:10.1080/17512786.2013.865964

Svensson, M. (2014). Voice, power and connectivity in China's microblogosphere: Digital divides on SinaWeibo. China Information, 28(2), 168-188. doi:10.1177/0920203X14540082

Thurman, N., \& Walters, A. (2013). Live blogging-Digital journalism's pivotal platform? A case study of the production, consumption, and form of live blogs at Guardian.co.uk. Digital Journalism, 1(1), 82-101. doi:10.1080/21670811.2012.714935

Tong, J. (2015). Chinese journalists' views of usergenerated content producers and journalism: A case study of the boundary work of journalism. Asian Journal of Communication, 25(6), 600-616. doi:10.1080/ 01292986.2015 .1019526

Usher, N. (2017). The appropriation/amplification model of citizen journalism: An account of structural limitations and the political economy of participatory content creation. Journalism Practice, 11(2/3), 247-265. doi:10.1080/17512786.2016.1223552

Wall, M. (2017). Mapping citizen and participatory journalism: In newsrooms, classrooms and beyond. Journalism Practice, 11(2/3), 134-141. doi:10.1080/ 


\subsection{6 .1245890}

Wang, S. (2015, August 13). The New York Times built a Slack bot to help decide which stories to post to social media. NiemanLab. Retrieved from http:// www.niemanlab.org

Wang, Y. (2018). Ecological conflation of digital technology and street politics: Alternative media in Hong Kong. Presented at the 68th Annual Conference of the International Communication Association, Prague, Czech Republic.

White, S. A., Nair, K. S., \& Ascroft, J. R. (Eds.). (1994). Participatory communication: Working for change and development. New Delhi and Thousand Oaks: Sage.

$\mathrm{Xu}$, D. (2015). Online censorship and journalists' tac- tics: A Chinese perspective. Journalism Practice, 9(5), 704-720. doi:10.1080/17512786.2014.982968

$\mathrm{Yu}, \mathrm{H}$. (2011). Beyond gatekeeping: J-blogging in China. Journalism, 12(4), 379-393. doi:10.1177/ 1464884910388229

Zhao, Y. (2011). Understanding China's media system in a world historical context. In D. C. Hallin \& P. Mancini (Eds.), Comparing media systems beyond the Western world (pp. 143-174). Cambridge: Cambridge University Press. doi:10.1017/CBO9781139005098.009

Zukin, C., Keeter, S., Andolina, M., Jenkins, K., \& Delli Carpini, M. (2006). New engagement?: Political participation, civic life, and the changing American citizen. New York, NY: Oxford University Press.

\section{About the Authors}
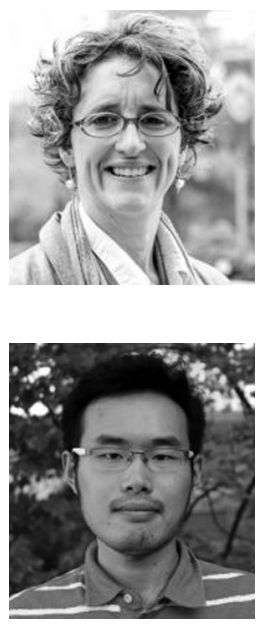

Sue Robinson (PhD, Temple University, 2007) holds the Helen Firstbrook Franklin Professor of Journalism endowed chair in the University of Wisconsin-Madison's School of Journalism \& Mass Communication. There she teaches and researches how the use of digital technologies in media ecologies can enhance and stymie participation among citizens. Her book, Networked News, Racial Divides: How Power and Privilege Shape Public Discourse in Progressive Communities (Cambridge University Press, 2018), explores new content-production roles in the information streams of highly liberal, mid-sized cities in the discussion of $\mathrm{K}-12$ racial disparities.

Yidong Wang is a PhD student at the School of Journalism and Mass Communication, University of Wisconsin-Madison. His research focuses on the intersection of media technologies and cultural and political discourses, especially within a global context. His past works include a master thesis about the civic participation on digital media in the Hong Kong localist movement. 